\title{
DESAIN DEDAKTIS PADA MATERI HUKUM KEPLER BERDASARKAN HAMBATAN BELAJAR SISWA KELAS X SEKOLAH MENENGAH ATAS
}

\author{
Liza Heryanti ${ }^{\text {a) }}$, Parsaoran Siahaan ${ }^{\text {b) }}$, Agus Fany Chandra Wijaya ${ }^{\text {c) }}$, \\ Heni Rusnayatid
}

Program Studi Pendidikan Fisika Fakultas Pendidikan Matematika dan Ilmu Pengetahuan Alam, Universitas Pendidikan Indonesia Jl. Dr. Setiabudhi No. 229 Bandung 40154, Indonesia

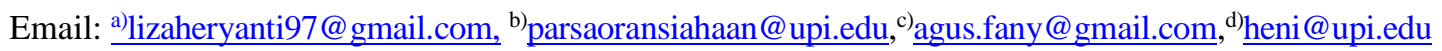

\begin{abstract}
Abstrak
Penelitian ini dilakukan karena besarnya hambatan pada materi hukum Kepler yaitu yang pertama hukum 1 Kepler mengenai bentuk orbit planet sebanyak 76,3\% siswa mempunyai hambatan yang tinggi, kedua yaitu hukum 2 kepler mengenai gerak planet sebanyak 82,5\% siswa mempunyai hambatan yang tinggi, ketiga yaitu hukum 3 Kepler mengenai hubungan revolusi planet dengan jarak planet ke Matahari sebanyak 92,1\% siswa mempunyai hambatan yang tinggi. Untuk mengatasi hal tersebut dilakukan penelitian tentang Didactical Design Research (DDR) atau sebuah desain pembelajaran yang dirancang untuk mengurangi hambatan belajar siswa. Dalam merancang DDR, dilakukan analisis hambatan epistimologis dengan menggunakan TKR (Tes Kemampuan Responden) dan hambatan ontogenik dengan menggunakan angket kesiapan belajar siswa. Desain yang dirancang diimplementasikan di kelas $\mathrm{X}$ IPA sebanyak tiga kali implementasi. Dari implementasi ketiga didapatkan hasil analisis TKR yang menunjukan penurunan hambatan belajar yang paling tinggi. Yang pertama pada hukum 1 Kepler menjadi 4,5\%, pada hukum 2 kepler menjadi 8,1\%, dan pada hukum 3 Kepler menjadi 12,6 \%. Hasil tersebut membuktikan bahwa desain didaktis yang digunakan mampu menangani sebagian besar hambatan belajar siswa.
\end{abstract}

Kata-kata kunci: Desain didaktis, Hambatan belajar, Hukum Kepler.

\begin{abstract}
This research held because the amount of obstacles in Kepler's Law subject that is Kepler's first law about the shape of the planet orbit as many as 76,3\% student have high learning obstacles, next is Kepler's second law about planet motion as many as $82,5 \%$ student have high learning obstacles, and last is Kepler's third law about relationship between the planetary revolution period and planetary distance to the sun as many as $92,1 \%$ student have high learning obstacles. To resolve that, this research is about Didactical Design Research (DDR) or a learning design which made for reduce learning obstacle. In making DDR, have epistemology learning obstacles analysis from TKR (Tes Kemampuan Responded/Responden Ability Test) and ontogenic learning obstacles from student learning readiness questionnaire. The design has implemented in the class Ten sains until three times. From the third implemented have an analysis TKR that show the high decline of student learning obstacles. Learning obstacles from Kepler's first law become 4,5\%, fom Kepler's second law become 8,1\%, and from Kepler's third law become $12,6 \%$. The result prove that the didactical design can handle mostly student learning obstacles.
\end{abstract}

Keywords: Didactical design, learning obstacles, Kepler's Law 


\section{PENDAHULUAN}

Kegiatan Pembelajaran adalah suatu proses yang mengandung serangkaian kegiatan guru dan siswa atas dasar hubungan timbal balik yang berlangsung dalam situasi edukatif untuk mencapai tujuan tertentu. Dalam kegiatan pembelajaran sering dijumpai berbagai masalah yang muncul dari hambatan belajar siswa itu sendiri. Baik itu hambatan yang berasal dari kesiapannya sendiri ketika akan menerima pembelajaran maupun hambatan terhadap materi yang diajarkan atau bagaimana cara materi tersebut disampaikan oleh guru. Untuk mengatasi beberapa masalah tersebut diperlukan upaya untuk mengurangi berbagai hambatan belajar siswa. Hambatan belajar tersebut menurut Brosseau (2002) dibagi menjadi tiga, yaitu [1]:

- Hambatan didaktis, adalah hambatan belajar yang muncul akibat dari kekeliruan proses pembelajaran, biasanya dapat berupa penyampaian materi yang kurang tepat oleh pendidik ke peserta didik.

- Hambatan ontogenik, adalah keterbatasan (neurofisiologis) siswa pada saat perkembangannya. Siswa yang mengalami hambtan belajar ini, salah satu penyebabnya karena siswa tidak mengalami pola perkembangan kognitif seperti seharusnya.

- Hambatan epistimologis, adalah hambatan belajar yang muncul akibat keterbatasan konteks peserta didik dalam memahami suatu konsep. Sehingga ketika disajikan suatu permasalahan dengan konsep yang sama namun konteks yang berbeda peserta didik tidak dapat menyelesaikannya.

Salah satu upaya untuk mengurangi berbagai hambatan belajar yang dialami siswa adalah perlu adanya penyusunan rancangan pembelajaran oleh guru dengan mempertimbangkan proses interaksi antara siswa, guru dan sumber belajar serta mempertimbangkan hambatan belajar siswa sebagai prediksi respon yang kemungkinan muncul dari siswa selama ataupun setelah proses pembelajaran berlangsung. Rancangan pembelajaran tersebut mencakup berbagai situasi didaktis serta pedagogis yang relevan dalam mengantisipasi berbagai respon siswa. Upaya tersebut dikenal dengan Penelitian Desain Didaktis atau Didactical Design Research (DDR).

Suryadi menyatakan bahwa dalam Didactical Design Research, terdapat tiga fase proses berpikir guru, yaitu 1) sebelum pembelajaran, 2) pada saat pembelajaran berlangsung, dan 3) setelah pembelajaran. Analisis dari ketiga fase tersebut akan menghasilkan suatu desain didaktis yang baru dan inovatif. Desain didaktis adalah suatu rangkaian dari situasi-situasi didaktis yang dikembangkan. Sebuah desain didaktis diharapkan dapat mengatasi semua hambatan belajar yang dialami siswa sehingga siswa dapat belajar dengan optimal. Oleh karena itu, perlu adanya sebuah penyusunan desain didaktis yang sesuai dalam mengajarkan fisika agar hambatan belajar yang muncul dapat diatasi semaksimal mungkin [2].

\section{METODOLOGI}

Jenis penelitian yang digunakan adalah kualitatif dengan desain deskriptif kualitatif. Menurut Sugiyono menyebutkan bahwa metode penelitian kualitatif adalah metode penelitian yang berdasarkan pada filsafat postpositivisme, digunakan untuk meneliti kondisi objek yang alamiah. Berarti objek dibiarkan berkembang apa adanya dan tidak dimanipulasi oleh peneliti. Desain pembelajaran yang digunakan dalam penelitian ini adalah Didactical Desain Research (DDR) [3]. Menurut Suryadi, tahapan yang harus ditempuh selama penelitian ini adalah sebagai berikut [2]:

- Analisis Situasi Didaktis

Tahapan ini dilakukan sebelum pelajaran berlangsung dan diwujudkan dalam bentuk Desain Didaktis Hipotesis termasuk Antisipasi Didaktis Pedagogis (ADP).

- Analisis Metapedadidaktik

Pada tahap ini berlangsung kegiatan: Pelaksanaan implementasi desain didaktis yang telah dibuat dan menganalisis hasil implementasi desain didaktis berbagai respon siswa saat implementasi desain didaktis. 


\section{- Analisis Retrosfektif}

Analisis restrospektif adalah tahapan yang mengaitkan hasil analisis situasi didaktis hipotesis dengan hasil analisis metapedadidaktik.

Desain didaktis yang dirancang telah melalui studi literatur dan perbandingan terhadap penelitian mengenai desain didaktis sebelumnya [4-6]. Penelitian ini dilaksanakan di salah satu SMA Negeri di kota Bandung dengan subjek penelitian adalah kelas XI dan X MIPA. Subjek penelitian kelas XI digunakan untuk mencari data awal yaitu data hambatan belajar siswa pada materi hukum Kepler dan kesiapan belajar siswa. Data tersebut kemudian dianalisis dan digunakan untuk membuat sebuah desain didaktis yang pertama. Desain didaktis tersebut kemudian diimplementasikan di kelas X untuk melihat apakah desain tersebut mampu meminimalisir hambatan belajar siswa. Untuk mengukur keberhasilannya, dilaksanakan Tes Kemampuan Responden diakhir pembelajaran. Kemudian hasilnya dianalisis untuk membuat desain didaktis yang lebih efektif lagi. Dalam penelitian ini dilakukan sampai tiga kali implementasi pembelajaran yang artinya terdapat tiga desain didaktis yang berasal dari data TKR awal untuk membuat desain pada implementasi pertama, lalu pada implementasi pertama akan menghasilkan data TKR 1 untuk membuat desain kedua yang diimplementasikan, pada implementasi kedua juga dihasilkan data TKR 2 yang kemudian dianalisis dan membuat desain ketiga. Penelitian ini menghasilkan suatu desain didaktis yang telah mengalami revisi sebanyak tiga kali. Untuk menghasilkan desain didaktis yang bisa meminimalisir hambatan belajar siswa, diperlukan analisis terhadap hasil TKR dan angket kesiapan belajar siswa. Analisis tersebut kemudian membentuk sebuah pola seperti pada tabel dibawah ini:

TABEL 1.

Pola Hambatan Epistimologis dan Hambatan Ontogenik

\begin{tabular}{|l|l|l|}
\hline \multirow{2}{*}{ No } & Pola Hambatan \\
\cline { 2 - 3 } & Epistimologis & Ontogenik \\
\hline & Tinggi & Tinggi \\
\hline & Tinggi & Rendah \\
\hline & Rendah & Tinggi \\
\hline & Rendah & Rendah \\
\hline
\end{tabular}

Adapun makna pola hambatan pada tabel tersebut, yaitu :

Pola 1 : Siswa tidak siap untuk belajar sehingga berpengaruh kepada tingginya hambatan epistimologis.

Pola 2 : Siswa siap untuk belajar, namun desain didaktis pembelajaran tidak baik, sehingga berpengaruh kepada tingginya hambatan epistimologis

Pola 3 : Siswa tidak siap untuk belajar, namun desain didaktis pembelajaran baik sehingga dapat mengantisipasi hambatan epistimologis

Pola 4 : Siswa siap belajar dan didukung dengan desain didktis pembelajaran yang baik sehingga dapat mengantisipasi hambatan epistimologis [7].

\section{HASIL DAN PEMBAHASAN}

Berdasarkan hasil Tes Kemampuasn Responden (TKR) awal diperoleh data hambatan epistimologis dan hambatan ontogenik siswa yang kemudian dianalisis untuk dibuat desain didaktis. Dan desain didaktis tersebut diimplementasikan untuk melihat apakah desain tersebut mampu meminimalisir hambatan belajar siswa. Untuk mengukur keberhasilannya, dilaksanakan Tes Kemampuan Responden diakhir pembelajaran yang akan menunjukan hambatan epistimologisnya. Sedangkan hambatan ontogenik diperoleh dari angket kesiapan belajar siswa. Kemudian hasilnya dianalisis untuk membuat desain didaktis akhir yang lebih efektif lagi. Adapun hasilnya dapat dilihat dalam tabel dibawah ini: 
TABEL 2.

Hambatan Epistimologis Siswa pada TKR Awal sampai Akhir

\begin{tabular}{|c|c|c|c|c|c|c|}
\hline No. & $\begin{array}{l}\text { Sub } \\
\text { Materi }\end{array}$ & Hambatan & $\begin{array}{l}\text { TKR } \\
\text { Awal }\end{array}$ & $\begin{array}{c}\text { TKR } \\
1\end{array}$ & $\begin{array}{c}\text { TKR } \\
2\end{array}$ & $\begin{array}{c}\text { TKR } \\
3\end{array}$ \\
\hline \multirow[t]{6}{*}{1} & \multirow[t]{6}{*}{$\begin{array}{l}\text { Hukum } 1 \\
\text { Kepler }\end{array}$} & $\begin{array}{l}\text { a. Tidak dapat menjelaskan bentuk orbit } \\
\text { planet dan posisi Matahari berdasarkan } \\
\text { hukum Kepler I }\end{array}$ & $52,6 \%$ & $\begin{array}{c}28,1 \\
\%\end{array}$ & $\begin{array}{c}15,6 \\
\%\end{array}$ & $0 \%$ \\
\hline & & $\begin{array}{l}\text { b. Tidak dapat mengidentifikasi gerak planet } \\
\text { ketika mengelilingi Matahari }\end{array}$ & $63,2 \%$ & $\begin{array}{c}43,8 \\
\%\end{array}$ & $63 \%$ & $3 \%$ \\
\hline & & $\begin{array}{l}\text { c. Tidak dapat menganalisis posisi Matahari } \\
\text { jika kecepatan planet pada posisi tertentu } \\
\text { lebih besar di posisi lain }\end{array}$ & $68,4 \%$ & $9,4 \%$ & $6,3 \%$ & $0 \%$ \\
\hline & & $\begin{array}{l}\text { d. Tidak dapat menentukan posisi Matahari } \\
\text { jika diketahui posisi planet dan kecepatan } \\
\text { planetnya }\end{array}$ & $89,5 \%$ & $\begin{array}{c}56,3 \\
\%\end{array}$ & $\begin{array}{c}15,6 \\
\%\end{array}$ & $3 \%$ \\
\hline & & $\begin{array}{l}\text { Tidak dapat mengurutkan kecepatan } \\
\text { planet dari yang terbesar ke terkecil } \\
\text { berdasarkan posisinya }\end{array}$ & $94,7 \%$ & $\underset{\%}{21,9}$ & $25 \%$ & $9,1 \%$ \\
\hline & & $\begin{array}{l}\text { f. Tidak dapat menentukan posisi perihelion } \\
\text { dan aphelion suatu planet }\end{array}$ & $89,5 \%$ & $\begin{array}{c}18,8 \\
\%\end{array}$ & $9,4 \%$ & $6,1 \%$ \\
\hline \multirow[t]{3}{*}{2.} & \multirow[t]{3}{*}{$\begin{array}{l}\text { Hukum } 2 \\
\text { Kepler }\end{array}$} & $\begin{array}{l}\text { a. Tidak dapat menganalisis besar luasan } \\
\text { orbit yang dibentuk planet dan Matahari } \\
\text { berdasarkan hukum } 2 \text { Kepler }\end{array}$ & $63,2 \%$ & $9,4 \%$ & $\begin{array}{c}12,5 \\
\%\end{array}$ & $6,1 \%$ \\
\hline & & $\begin{array}{l}\text { b. Tidak dapat menganalisis waktu yang } \\
\text { ditempuh planet pada posisi tertentu } \\
\text { berdasarkan hukum } 2 \text { Kepler }\end{array}$ & $89.5 \%$ & $\begin{array}{c}53,1 \\
\%\end{array}$ & $\begin{array}{c}46,9 \\
\%\end{array}$ & $9,1 \%$ \\
\hline & & $\begin{array}{l}\text { c. Tidak dapat menjelaskan besar luasan } \\
\text { orbit yang dibentuk planet dan Matahari } \\
\text { berdasarkan hukum 2 Kepler }\end{array}$ & $94,7 \%$ & $75 \%$ & $\begin{array}{c}56,25 \\
\%\end{array}$ & $9,1 \%$ \\
\hline \multirow[t]{6}{*}{3.} & \multirow[t]{6}{*}{$\begin{array}{l}\text { Hukum } 3 \\
\text { Kepler }\end{array}$} & $\begin{array}{l}\text { a. Tidak dapat menjelaskan hubungan antara } \\
\text { periode revolusi planet dan jarak rata-rata } \\
\text { planet ke Matahari berdasarkan hukum } 3 \\
\text { Kepler }\end{array}$ & $73,7 \%$ & $25 \%$ & $\begin{array}{c}18,75 \\
\%\end{array}$ & $3 \%$ \\
\hline & & $\begin{array}{l}\text { b. Tidak mengetahui persamaan matematis } \\
\text { untuk mencari jarak planet ke Matahari }\end{array}$ & $78,9 \%$ & $9,4 \%$ & $9,4 \%$ & $6,1 \%$ \\
\hline & & $\begin{array}{l}\text { c. Tidak dapat menentukan jarak planet ke } \\
\text { Matahari }\end{array}$ & $100 \%$ & $31,3 \%$ & $\begin{array}{c}21,9 \\
\%\end{array}$ & $\begin{array}{c}18,18 \\
\%\end{array}$ \\
\hline & & $\begin{array}{l}\text { d. Tidak dapat menentukan periode revolusi } \\
\text { planet }\end{array}$ & $100 \%$ & $\begin{array}{c}40,6 \\
\%\end{array}$ & $25 \%$ & $\begin{array}{c}15,15 \\
\%\end{array}$ \\
\hline & & $\begin{array}{l}\text { e. Tidak dapat menjelaskan makna fisis dari } \\
\text { persamaan hukum Kepler III mengenai } \\
\text { jarak planet ke Matahari }\end{array}$ & $100 \%$ & $\begin{array}{c}65,2 \\
\%\end{array}$ & $\begin{array}{c}31,3 \\
\%\end{array}$ & $\begin{array}{c}15,15 \\
\%\end{array}$ \\
\hline & & $\begin{array}{l}\text { f. Tidak dapat menjelaskan makna fisis dari } \\
\text { persamaan hukum Kepler III mengenai } \\
\text { jarak planet ke Matahari }\end{array}$ & $100 \%$ & $\begin{array}{c}40,6 \\
\%\end{array}$ & $\begin{array}{c}21,9 \\
\%\end{array}$ & $\begin{array}{c}18,18 \\
\%\end{array}$ \\
\hline
\end{tabular}

Dari tabel diatas dapat dilihat hambatan epistimologis siswa dari TKR awal sampai TKR 3 mengalami penurunan yang sangat besar. Misalnya yaitu pada nomor 1c yang mempunyai hambatan sebesar $68,4 \%$ pada TKR awal menjadi $0 \%$ pada TKR 3. Hal tersebut membuktikan bahwa desain didaktis yang diimplementasikan sangat optimal untuk mengurangi hambatan belajar siswa.

TABEL 3.

\begin{tabular}{ccccc}
$\begin{array}{c}\text { Kategori Pola } \\
\text { Hambatan }\end{array}$ & $\begin{array}{c}\text { Hambatan Ontologi Siswa dari TKR Awal sampai Akhir } \\
\text { Persentase pada } \\
\text { TKR Awal }\end{array}$ & $\begin{array}{c}\text { Persentase } \\
\text { pada TKR 1 }\end{array}$ & $\begin{array}{c}\text { Persentase pada } \\
\text { TKR 2 }\end{array}$ & $\begin{array}{c}\text { Persentase } \\
\text { pada TKR 3 }\end{array}$ \\
\hline Tinggi & $68,4 \%$ & $45,2 \%$ & $50 \%$ & $30,3 \%$ \\
\hline Rendah & $31,6 \%$ & $54,8 \%$ & $50 \%$ & $69,7 \%$ \\
\hline Sinn
\end{tabular}

Selain menggunakan hambatan epistimologis, dalam membuat desain didaktis juga menggunakan analisis hambatan ontogenik yang dihubungkan dengan hambatan epistimologis. Adapun hubungan antara hambatan epistimologis dan hambatan ontogenik dapat dilihat dalam tabel dibawah ini: 
TABEL 4.

Pola Hambatan Epistimologis dan Hambatan Ontogenik pada TKR Awal

\begin{tabular}{|c|c|c|c|c|}
\hline \multirow[t]{2}{*}{ No } & \multicolumn{2}{|c|}{ Pola Hambatan } & \multirow[t]{2}{*}{ Banyaknya } & \multirow{2}{*}{$\begin{array}{l}\text { Persentase } \\
(\%)\end{array}$} \\
\hline & Epistimologis & Ontologi & & \\
\hline 1 & Tinggi & Tinggi & 13 & 68,4 \\
\hline 2 & Tinggi & Rendah & 6 & 31,6 \\
\hline 3 & Rendah & Tinggi & 0 & 0 \\
\hline 4 & Rendah & Rendah & 0 & 0 \\
\hline
\end{tabular}

Tabel diatas menunjukan empat pola hambatan epistimologis dan ontogenik yang dimiliki oleh siswa. Hambatan epistimologis dan hambatan ontogenik saling berhubungan. Hubungan pertama dapat dilihat dari pola yang pertama dimana terdapat 13 siswa yang mempunyai hambatan epistimologis tinggi dan hambatan ontogenik yang tinggi juga. Hambatan ontogenik (kesiapan siswa) mempengaruhi hambatan epistimologis. Jika kesiapan siswa kurang baik atau hambatan ontogenikya tinggi maka siswa tersebut akan sulit memahami pembelajaran yang sedang berlangsung sehingga memiliki hambatan epistimologis yang tinggi juga.

Pada pola kedua, terdapat 6 siswa yang memiliki hambatan epistimologis tinggi tetapi memiliki hambatan ontogenik yang rendah. Hal ini berarti kesiapan belajar siswa tersebut sudah baik namun kegiatan proses pembelajaran materi hukum Kepler yang dilakukan guru fisika di kelas ini kurang baik sehingga menyebabkan tingginya hambatan epistemologis siswa. Berdasarkan hal tersebut, maka diperlukan adanya desain didaktis yang disusun berdasarkan respon siswa dan dapat mengatasi hambatan epistemologis yang dialami siswa.

Penyusunan desain didaktis pada penelitian ini dilakukan hingga tiga kali penyusunan yang artinya menghasilkan tiga desain dimana desain yang ketiga merupakan revisi dari desain yang pertama dan kedua. Dari hasil analisis yang ditunjukan pada TABEL 1 terlihat bahwa hambatan yang paling kecil terdapat pada TKR 3 yang merupakan hasil dari implementasi desain didaktis yang ketiga. Oleh karena itu desain didaktis yang ketiga merupakan desain yang paling efektif untuk menurunkan hambatan belajar siswa. Bukti lainnya bisa dilihat dari tabel dibawah ini mengenai pola hambatan epistimologis dan hambatan ontogenik pada TKR 3:

TABEL 5.

Pola Hambatan Epistimologis dan Hambatan Ontogenik pada TKR 3

\begin{tabular}{ccccc}
\hline No & \multicolumn{2}{c}{ Pola Hambatan } & Banyaknya & $\begin{array}{c}\text { Persentase } \\
\end{array}$ \\
\cline { 2 - 3 } & Epistimologis & Ontologi & & 0 \\
\hline 1 & Tinggi & Tinggi & 0 & 0 \\
\hline 2 & Tinggi & Rendah & 0 & 0 \\
\hline 3 & Rendah & Tinggi & 10 & 30,3 \\
\hline 4 & Rendah & Rendah & 23 & 69,7 \\
\hline
\end{tabular}

TABEL 5. Menunjukan pola hambatan epistimologis dan hambatan ontogenik pada TKR 3. Ada empat pola yang dapat dianalisis, untuk pola yang pertama dan kedua adalah pola dengan hambatan epistimologis yang tinggi dan ternyata tidak ada lagi siswa yang mempunyai hambatan epistimologis yang tinggi. Sedangkan pola yang ketiga menunjukan bahwa ada 10 dari 33 siswa yang mempunyai hambatan epistimologis rendah tetapi masih mempunyai hambatan ontogenik tinggi. Artinya, siswa tersebut belum siap untuk mengikuti pembelajaran tetapi karena pembelajaran yang dilaksanakan dikelas cukup bagus sehingga mempunyai hambatan epistimologis yang rendah. Pola keempat menunjukan bahwa ada 23 dari 33 siswa yang mempunyai hambatan epistimologis dan hambatan ontogenik yang rendah. Artinya, hambatan ontogenik dan hambatan epistimologis saling mempengaruhi sehingga ketika siswa siap mengikuti pembelajaran dan didukung dengan desain pembelajaran yang baik maka bisa meminimalisir hambatan belajar yang dimiliki siswa tersebut.

Desain didaktis yang digunakan dibuat berdasarkan hasil analisis hambatan epistimologis dari TKR dan hambatan Ontogenik dari angket kesiapan belajar. Secara singkat, kegiatan pembelejaran pada desain ketiga dibagi menjadi kegiatan pembuka, inti dan penutup. Kegiatan pembuka diawali dengan membaca doa lalu guru memberikan apersepsi dengan pembelajaran pada pertemuan sebelumnya atau dengan fenomena yang terjadi: 
Seperti yang kita ketahui bahwa bumi planet tempat kita tinggal ini selalu bergerak setiap saatnya. Pernahkah kalian memikirkan jalan yang dilalui bumi kita ini ketika mengelilingi Matahari? Disebut apakah jalan yang dilintasi planet ketika mengelilingi Matahari?

Dari pertanyaan tersebut diharapkan siswa mulai membayangkan bagaiamana ketika planet mengelilingi Matahari, entah dari gerakannya maupun bentuk orbitnya. Setelah itu guru memberikan kesempatan kepada siswa untuk bertanya.

Selanjutnya yaitu kegiatan inti dengan pembahasan pertama yaitu hukum 1 Kepler mengenai bentuk orbit planet. Pada bagian ini siswa diberikan LKS terlebih dahulu dan dibagi menjadi beberapa kelompok dengan anggota 4-5 orang. Pada bahasan hukum 1 Kepler, siswa diminta untuk menggambar elips dengan bahan yang diberikan yaitu jarum, benang, sterofoam, dan kertas dengan berbekal petunjuk pada hukum 1 Kepler bahwa elips mempunyai dua titik fokus. Awalnya banyak siswa yang gagal dan malah menggambar lingkaran, tetapi setelah mencoba berkali-kali akhirnya ada siswa yang berhasil membuat gambar elips. Setelah itu siswa diminta untuk menjawab pertanyaan bagian satu pada LKS. Sebelum berlanjut ke bagian dua, salah satu kelompok diminta untuk mempresentasikan jawabannya terlebih dahulu sedangkan kelompok lainnya diperbolehkan untuk bertanya maupun menambahkan jawaban. Diakhir pembahasan ini, guru menampilkan simulasi phet dari gerak planet ketika mengelilingi Matahari. Pembahasan kedua pada kegiatan inti adalah mengenai hukum 2 Kepler yang diawali dengan menampilkan video simulasi gerak planet yang menjabarkan gerak planet membentuk suatu luasan yang sama dalam waktu yang sama. Dipembahasan ini juga siswa diminta untuk mengerjakan LKS pada bagian 2 dengan bimbingan guru. Dan seperti pembahasan pertama, akan ada kelompok yang presentasi dengan kelompok lainnya sebagai penanya. Guru juga memberikan pertanyaan tambahan dengan menampilkan sebuah gambar yang menunjukan garis khayal yang dibentuk planet dan Matahari membentuk sebuah luasan lalu siswa diminta untuk menganalisis gambar tersebut dan menjawab beberapa pertanyaan. Sebagai penutup, siswa diminta untuk menyimpulkan mengenai hukum 2 kepler tentang gerak planet. Pembahasan ketiga yaitu mengenai hukum 3 Kepler tentang hubungan periode revolusi planet dan jari-jari orbit planet ketika mengellingi Matahari. Pada bagian ini juga siswa harus mengisi LKS pada bagian 3 dengan berdiskusi. Pada bagian ini juga diberikan beberapa contoh soal untuk mencari periode revolusi planet maupun jarak planet ke Matahari dengan menggunakan perbandingan yang terdapat pada hukum 3 kepler. Dan untuk lebih memastikan pemahaman siswa, guru memberikan pertanyaan mengenai makna fisis pada hukum 3 Kepler.

Kegiatan terkahir yaitu penutup dimana siswa diminta untuk menyimpulkan pembelajaran hari ini dan guru memberikan refleksi terhadap pembelajaran juga. Setelah itu dilakukan penilaian yaitu siswa mengisi soal TKR dengan batas waktu yang sudah ditentukan. Hal ini untuk melihat apakah pembelajaran dengan menggunakan desain didaktis ini dapat meminimalisir hambatan belajar siswa.

Dan seperti yang telah dijelaskan sebelumnya bahwa dalam penelitian menghasilkan tiga desain dimana perbedaan ketiga desain tersebut dapat dilihat dalam tabel dibawah ini.

TABEL 6.

Perbandingan Desain Didaktis Pada Setiap Implementasi

\begin{tabular}{cll}
\hline Implementasi 1 & \multicolumn{1}{c}{ Implementasi 2 } & \multicolumn{1}{c}{ Implementasi 3 } \\
\hline Pada konsep esensial pertama & Pada konsep esensial pertama & Pada konsep esensial pertama \\
yaitu hukum 1 Kepler: Tidak yaitu hukum 1 Kepler: & yaitu hukum 1 Kepler: \\
ditampilkan gambar mengenai & $\begin{array}{l}\text { Ditampilkan gambar } \\
\text { bentuk orbit planet ketika }\end{array}$ & $\begin{array}{c}\text { Ditampilkan gambar mengenai } \\
\text { mentuk onai }\end{array}$ \\
$\begin{array}{ccc}\text { mengelilingi Matahari dan bentuk orbit planet ketika mengelilingi Matahari dan } \\
\text { bagaimana posisi Matahari. }\end{array}$ & $\begin{array}{l}\text { mengelilingi Matahari dan } \\
\text { bagaimana posisi Matahari. }\end{array}$ & $\begin{array}{l}\text { bagaimana posisi Matahari. } \\
\text { Dan } \\
\text { diakhir ditampilkan simulasi } \\
\text { phet mengenai bentuk orbit }\end{array}$ \\
\hline
\end{tabular}




\begin{tabular}{|c|c|c|}
\hline $\begin{array}{l}\text { Pada konsep esensial kedua } \\
\text { yaitu hukum } 2 \text { Kepler: } \\
\text { Proses diskusi hanya } \\
\text { menggunakan pertanyaan- } \\
\text { pertanyaan dalam LKS } \\
\text { saja. }\end{array}$ & $\begin{array}{l}\text { Pada konsep esensial kedua } \\
\text { yaitu hukum 2 Kepler: Proses } \\
\text { diskusi menggunakan } \\
\text { pertanyaan dalam LKS dan } \\
\text { pertanyaan tambahan dari } \\
\text { guru } \\
\text { dengan menampilkan sebuah } \\
\text { gambar yang menunjukan } \\
\text { garis khayal yang dibentuk } \\
\text { planet } \\
\text { dan Matahari membentuk } \\
\text { sebuah luasan lalu siswa } \\
\text { diminta untuk menganalisis } \\
\text { gambar tersebut dan } \\
\text { menjawab beberapa } \\
\text { pertanyaan. }\end{array}$ & $\begin{array}{l}\text { Pada konsep esensial kedua } \\
\text { yaitu hukum } 2 \text { Kepler: Proses } \\
\text { diskusi menggunakan } \\
\text { pertanyaan dalam LKS dan } \\
\text { pertanyaan tambahan dari guru } \\
\text { dengan menampilkan sebuah } \\
\text { gambar yang menunjukan } \\
\text { garis khayal yang dibentuk } \\
\text { planet dan } \\
\text { Matahari membentuk sebuah } \\
\text { luasan lalu siswa diminta } \\
\text { untuk } \\
\text { menganalisis gambar tersebut } \\
\text { dan menjawab beberapa } \\
\text { pertanyaan. Sebagai penutup, } \\
\text { siswa diminta untuk } \\
\end{array}$ \\
\hline $\begin{array}{l}\text { Pada konsep esensial ketiga } \\
\text { yaitu hukum } 3 \text { Kepler: } \\
\text { siswa hanya menyelesaikan } \\
\text { latihan soal yang ada dalam } \\
\text { LKS. }\end{array}$ & $\begin{array}{l}\text { Pada konsep esensial ketiga } \\
\text { yaitu hukum } 3 \text { Kepler: siswa } \\
\text { menyelesaikan latihan soal } \\
\text { yang } \\
\text { ada dalam LKS dan yang } \\
\text { diberikan guru diakhir } \\
\text { pembelajaran. }\end{array}$ & $\begin{array}{l}\text { Pada konsep esensial ketiga } \\
\text { yaitu hukum } 3 \text { Kepler: siswa } \\
\text { menyelesaikan latihan soal } \\
\text { yang } \\
\text { ada dalam LKS dan yang } \\
\text { diberikan guru diakhir } \\
\text { pembelajaran. Dan untuk lebih } \\
\text { memastikan pemahaman } \\
\text { siswa, } \\
\text { guru memberikan pertanyaan } \\
\text { mengenai makna fisis pada } \\
\text { hukum } 3 \text { Kepler. }\end{array}$ \\
\hline
\end{tabular}

SIMPULAN

Hambatan belajar yang dimiliki siswa terkait dengan materi hukum Kepler adalah : 1a) Tidak dapat menjelaskan bentuk orbit planet dan posisi Matahari berdasarkan hukum Kepler I, 1b) Tidak dapat mengidentifikasi gerak planet ketika mengelilingi Matahari, 1c) Tidak dapat menganalisis posisi matahari jika kecepatan planet pada posisi tertentu lebih besar di posisi lain, 1d) Tidak dapat menentukan posisi Matahari jika diketahui posisi planet dan kecepatan planetnya, 1e) Tidak dapat mengurutkan kecepatan planet dari yang terbesar ke terkecil berdasarkan posisinya, 1f) Tidak dapat menentukan posisi perihelion dan aphelion suatu planet. 2a) Tidak dapat menganalisis besar luasan orbit yang dibentuk planet dan Matahari berdasarkan hukum 2 Kepler, 2c) Tidak dapat meng analisis waktu yang ditempuh planet pada posisi tertentu berdasarkan hukum 2 Kepler, Tidak dapat menjelaskan besar luasan orbit yang dibentuk planet dan Matahari berdasarkan hukum 2 Kepler. 3a) Tidak dapat menjelaskan hubungan antara periode revolusi planet dan jarak rata-rata planet ke Matahari berdasarkan hukum 3 Kepler, 3b) Tidak mengetahui persamaan matematis untuk mencari jarak planet ke Matahari, 3c) Tidak dapat menentukan jarak planet ke Matahari, 3d) Tidak dapat menentukan periode revolusi planet, 3e) Tidak dapat menjelaskan makna fisis dari persamaan hukum Kepler III mengenai jarak planet ke Matahari, dan 3f) f. Tidak dapat menjelaskan makna fisis dari persamaan hukum Kepler III mengenai jarak planet ke Matahari.

Hampir seluruh hambatan belajar mengalami penurunan dari mulai implementasi pertama sampai implementasi ketiga. Penurunan yang paling besar ada pada implementasi ketiga yang artinya desain didaktis yang digunakan sangat optimal untuk meminimalisir hambatan belajar siswa. 


\section{REFERENSI}

[1] Brousseau, Guy . 2002. Theory of didactical Situations in Mathematic. New York : Kluwer Academic Publisher

[2] Suryadi, Didi. 2010. Teori, Paradigma, Prinsip, dan Pendekatan Pembelajaran MIPA dalam Konteks Indonesia. Bandung: FPMIPA UPI.

[3] Sugiyono. (2014). Metode Penelitian Pendidikan (Pendekatan Kuantitatif, Kualitatif, dan R\&D). Bandung : Alfabeta.

[4] Rusnayati, H., Stefani, R., \& Wijaya, A. F. C. (2015). Desain Didaktis Pembelajaran Konsep Energi dan Energi Kinetik Berdasarkan Kesulitan Belajar Siswa pada Sekolah Menengah Atas. Jurnal Penelitian \& Pengembangan Pendidikan Fisika, 1(1), 69 - 76.

[5] Marieta, W. F. D., Rusnayati, H., \& Wijaya, A. F. C. (2016). Desain Didaktis Konsep Gradien Grafik v(t) sebagai Percepatan atau Perlambatan berdasarkan Hambatan Belajar Peserta Didik Kelas X SMA. Jurnal Penelitian \& Pengembangan Pendidikan Fisika, 2(2), $105-112$.

[6] Susana, S., \& Sriyansyah, S. (2015). Analisis Didaktis Berdasarkan Kemampuan Kognitif dan Keterampilan Berpikir Kritis Siswa pada Materi Kalor. Jurnal Penelitian \& Pengembangan Pendidikan Fisika, 1(2), 39 - 44.

[7] Herawati. (2017). Kesulitan Belajar Berlatar Interaksi Sosial Peserta Didik di Sekolah. (Skripsi). Program Studi Bimbingan dan Konseling, Universitas Pendidikan Indonesia, Bandung. 